\title{
Preparation and purification of Flavobacterium heparinum chondroitinases AC and B by hydrophobic interaction chromatography
}

J.A.K. Aguiar and Y.M. Michelacci
Departamento de Bioquímica, Escola Paulista de Medicina, Universidade Federal de São Paulo, São Paulo, SP, Brasil

\section{Correspondence \\ Y.M. Michelacci \\ Departamento de Bioquímica EPM, UNIFESP \\ Rua Três de Maio, 100 \\ 04044-020 São Paulo, SP \\ Brasil \\ Fax: + 55-11-573-6407 \\ E-mail: yara.bioq@epm.br \\ Presented at the 5th Brazilian Symposium on Extracellular Matrix - SIMEC, Angra dos Reis, \\ RJ, Brasil, September 7-10, 1998. \\ Research supported by CNPq, CAPES, FAPESP and FINEP.}

Received November 24, 1998

Accepted December 21, 1998

\begin{abstract}
Flavobacterium heparinum is a soil bacterium that produces several mucopolysaccharidases such as heparinase, heparitinases I and II, and chondroitinases AC, B, C and ABC. The purpose of the present study was to optimize the preparation of $F$. heparinum chondroitinases, which are very useful tools for the identification and structural characterization of chondroitin and dermatan sulfates. We observed that during the routine procedure for cell disruption (ultrasound, $100 \mathrm{kHz}$, $5 \mathrm{~min}$ ) some of the chondroitinase B activity was lost. Using milder conditions ( $2 \mathrm{~min}$ ), most of the chondroitinase B and AC protein was solubilized and the enzyme activities were preserved. Tryptic soy broth without glucose was the best culture medium both for bacterial growth and enzyme induction. Chondroitinases $\mathrm{AC}$ and $\mathrm{B}$ were separated from each other and also from glucuronidases and sulfatases by hydrophobic interaction chromatography on HP Phenyl-Sepharose. A rapid method for screening of the column fractions was also developed based on the metachromatic shift of the color of dimethylmethylene blue.
\end{abstract}

Key words

- Chondroitinases

- Mucopolysaccharidases

- Dermatan sulfate

- Chondroitin sulfate
Chondroitin and dermatan sulfates are the most common glycosaminoglycans in extracellular matrix proteoglycans (1). Chondroitin sulfate is a heteropolysaccharide made up largely of repeating disaccharide units, in which one sugar is $N$-acetyl-D-galactosamine and the other is D-glucuronic acid. The disaccharides can be sulfated at the 4 or 6 position of $N$-acetylgalactosamine. Dermatan sulfate is an isomer of chondroitin 4sulfate in which some of the D-glucuronic acid residues are replaced by L-iduronic acid.

Enzymatic methods have become increasingly important for the determination of the polysaccharide structure and are preferable to chemical methods. Two classes of enzymes act on glycosaminoglycans: prokaryotic lyases, which depolymerize glycosaminoglycans by an elimination mechanism (2) and eukaryotic enzymes, which act by hydrolysis $(3,4)$.

Flavobacterium heparinum produces four 
chondroitinases which form unsaturated disaccharides from dermatan and chondroitin sulfates, i.e., chondroitinases AC (5), B (6), $C$ (7) and $A B C$ (8). Using chondroitinases $\mathrm{AC}$ and $\mathrm{C}$, we have shown that cartilage chondroitin sulfate contains both 4-sulfated and 6-sulfated disaccharide units in variable proportions, depending on the species and age $(9,10)$ and using chondroitinases $B$ and $\mathrm{AC}$ we demonstrated that dermatan sulfates of different origins contain glucuronic and iduronic acid in different proportions and at variable positions (11).

These chondroitinases were isolated by agarose gel electrophoresis $(6,7)$ or by column chromatography procedures based on ion exchange (12), gel permeation (8), adsorption on hydroxyapatite (13), or affinity chromatography (14). However, agarose gel electrophoresis is very time consuming and provides pure enzymes in low yields whereas poor reproducibility was obtained for column chromatography, especially for hydroxyapatite and ion exchange media.

Here we describe improved conditions for bacterial growth and cell disruption, a reproducible scheme for purification of $F$. heparinum chondroitinases $\mathrm{AC}$ and $\mathrm{B}$, as well as a rapid assay for chondroitinase activities based on decrease of metachromatic shift of the color of dimethylmethylene blue.

The bacteria were maintained and grown as previously described (7). For batch culture, three culture media were used, with or without the addition of chondroitin sulfate as an inducer $(150 \mathrm{mg} / \mathrm{l})$ : meat peptone (10 $\mathrm{g} / \mathrm{l})$; tryptic soy broth $(17 \mathrm{~g} / \mathrm{l}$ casein peptone, $3 \mathrm{~g} / \mathrm{l}$ soy peptone, $2.5 \mathrm{~g} / \mathrm{l}$ glucose, $5 \mathrm{~g} / \mathrm{l} \mathrm{NaCl}$, $\left.2.5 \mathrm{~g} / \mathrm{l} \mathrm{K}_{2} \mathrm{HPO}_{4}\right)$, and tryptic soy broth without glucose $(17 \mathrm{~g} / \mathrm{l}$ casein peptone, $3 \mathrm{~g} / 1$ soy peptone, $\left.5 \mathrm{~g} / 1 \mathrm{NaCl}, 2.5 \mathrm{~g} / \mathrm{K} \mathrm{K}_{2} \mathrm{HPO}_{4}\right)$. The presence of chondroitin sulfate or glucose did not significantly affect bacterial growth rate. However, F. heparinum grew to a higher cell density in tryptic soy broth than in meat peptone. Furthermore, in peptone with or without the inducer, high specific activities for chondroitinases were obtained during the initial $6 \mathrm{~h}$, when the cell densities were low, but decreased thereafter. In contrast, in tryptic soy broth, high specific activities were obtained after $24 \mathrm{~h}$ growth in the presence of the inducer, generating large amounts of chondroitinase-rich extracts.

For the preparation of chondroitinasecontaining bacterial extracts, the cells grown in 1 liter glucose-free tryptic soy broth containing $150 \mathrm{mg}$ of chondroitin sulfate were collected by centrifugation, suspended in 5 $\mathrm{ml}$ of $50 \mathrm{mM}$ Tris-acetate buffer, $\mathrm{pH} 7.5$, and disrupted by sonication. Our routine procedure for sonication was $100 \mathrm{kHz}$ output, ten 30 -s pulses, and $4^{\circ} \mathrm{C}$ (7). Nevertheless, we now report that under milder conditions (four 30 -s pulses) most of the chondroitinases were solubilized and higher specific activities were obtained for chondroitinase B. Cell debris were removed by centrifugation at 100,000 $g$ for $60 \mathrm{~min}$ at $4^{\circ} \mathrm{C}$ and the supernatant thus obtained was maintained at $-20^{\circ} \mathrm{C}$.

Ammonium sulfate was added to $1 \mathrm{M}$ final concentration to aliquots of crude extracts containing $2 \mathrm{mg}$ of protein $(0.5-1 \mathrm{ml})$. These samples were applied to a high performance (HP) Phenyl-Sepharose column (0.4 $\mathrm{x} 2.0 \mathrm{~cm}, 1-\mathrm{ml}$ bed volume) previously equilibrated with $1 \mathrm{M}\left(\mathrm{NH}_{4}\right)_{2} \mathrm{SO}_{4}$ in $50 \mathrm{mM}$ Trisacetate buffer, $\mathrm{pH}$ 7.5. The enzymes were eluted in a stepwise fashion with 1-ml volumes containing decreasing concentrations of $\left(\mathrm{NH}_{4}\right)_{2} \mathrm{SO}_{4}$ in the same buffer $(1.00,1.00$, $0.88,0.75,0.62,0.50,0.38,0.25,0.12 \mathrm{M})$, followed by $10 \mathrm{ml}$ of ammonium sulfate-free buffer at a flow rate of $0.5 \mathrm{ml} / \mathrm{min}$. Onemilliliter fractions were collected and analyzed for protein and chondroitinase activities (Figure 1).

Total protein was estimated by the Coomassie blue method (15) and three enzyme assays were carried out to measure the chondroitinase activities as described below.

Dimethylmethylene blue. Samples containing enzyme $(10 \mu \mathrm{l}$ of fractions eluted from columns or $2 \mu 1$ of $F$. heparinum crude 
extracts) were incubated with $3 \mu \mathrm{g}$ of chondroitin sulfate or dermatan sulfate in 96-well plates. After 1-4-h incubation at room temperature, $100 \mu \mathrm{l}$ of dimethylmethylene blue reagent (16) was added and absorbance was measured at $620 \mathrm{~nm}$. The dye showed a metachromatic shift from blue to purple in the presence of sulfated glycosaminoglycans. This assay permits the determination of chondroitinase activities in both crude extracts and purified enzymes. Chondroitinase ACand chondroitinase B-containing fractions were pooled. For the determination of purification and recovery, mixtures $(200 \mu 1$ final volume) were prepared containing $200 \mu \mathrm{g}$ of substrate (chondroitin sulfate or dermatan sulfate) and aliquots of either crude extracts $(5 \mu l)$ or purified enzymes $(100 \mu l)$. Incubations were carried out at the optimum temperature of the particular lyase being assayed $\left(37^{\circ} \mathrm{C}\right.$ for chondroitinase $\mathrm{AC}$ and $20^{\circ} \mathrm{C}$ for chondroitinase $\mathrm{B})$. Aliquots $(10 \mu \mathrm{l})$ were collected at different times (0 to $120 \mathrm{~min}$ ), diluted to $100 \mu \mathrm{l}$ with water and $1 \mathrm{ml}$ of dimethylmethylene blue reagent was added. The changes in absorbance were measured at $525 \mathrm{~nm}$ immediately after dimethylmethylene blue addition, and compared to a standard curve of 0 to $10 \mu \mathrm{g}$ of chondroitin sulfate.

Paper chromatography. The fractions were dialyzed against $50 \mathrm{mM}$ Tris-acetate buffer, $\mathrm{pH} 7.5$, to remove the ammonium sulfate. Aliquots $(20 \mu \mathrm{l})$ of each dialyzed fraction were incubated with $50 \mu \mathrm{g}$ of chondroitin sulfate or dermatan sulfate. After overnight incubation at $37^{\circ} \mathrm{C}$ (for chondroitin sulfate) or $20^{\circ} \mathrm{C}$ (for dermatan sulfate), the incubation mixtures were submitted to heat inactivation and to paper chromatography as described (7).

Absorbance at $232 \mathrm{~nm}$. The activities of the purified enzymes were also measured by the increase in absorbance at $232 \mathrm{~nm}$ as a function of time. Samples $(100 \mu l)$ were added to cuvettes containing $1 \mathrm{ml}$ of $1 \mathrm{mg} / \mathrm{ml}$ chondroitin sulfate or dermatan sulfate in 50
$\mathrm{mM}$ Tris-acetate buffer, $\mathrm{pH} 7.5$, under the appropriate temperature conditions. This method proved to be useful for measuring purified chondroitinases, but was ineffective for crude extracts due to the presence of glucuronidases which degraded the unsaturated disaccharides formed.

Figure 1 shows that chondroitin sulfateand dermatan sulfate-degrading activities were separated by hydrophobic interaction chromatography (HIC) on HP PhenylSepharose. The products formed were also analyzed by paper chromatography (Figure 1B). Fractions 5 to 9 contain chondroitinase AC, which degrades chondroitin sulfate producing unsaturated sulfated disaccharides ( $\Delta$ Di6S and $\Delta$ Di4S) as main products. Fractions 8 and 9 also contain glucuronidase and sulfatase activity, which further degrade the disaccharides to $N$-acetylgalactosamine 6sulfate (GalNAc6S) and non-sulfated disaccharide $(\Delta \mathrm{Di} 0 \mathrm{~S})$, respectively. The main products formed from dermatan sulfate were unsaturated 4-sulfated disaccharide $(\Delta \mathrm{Di} 4 \mathrm{~S})$ and oligosaccharides (fractions 10 to 12), indicating that chondroitinase $\mathrm{B}$ did not elute together with glucuronidase or sulfatase. A 2 -fold purification with $57 \%$ yield was obtained for chondroitinase AC (fractions 5 to 7 ) and a 3 -fold purification with $66 \%$ yield was obtained for chondroitinase B (fractions 10 to 12 ) in this single purification step. Both chondroitinase AC and B preparations were completely free from other mucopolysaccharidases and also from glucuronidases and sulfatases.

For large scale preparation, a 10-ml HP Phenyl-Sepharose column was prepared (1.4 x $6.5 \mathrm{~cm})$ and eluted with a) $1 \mathrm{M}\left(\mathrm{NH}_{4}\right)_{2} \mathrm{SO}_{4}$ in Tris-acetate buffer $(40 \mathrm{ml})$, b) a linear gradient of 1 to $0 \mathrm{M}\left(\mathrm{NH}_{4}\right)_{2} \mathrm{SO}_{4}$ in Trisacetate buffer $(80 \mathrm{ml})$, and c) Tris-acetate buffer $(40 \mathrm{ml})$. Two-milliliter fractions were collected at a flow rate of $1 \mathrm{ml} / \mathrm{min}$. The results obtained were similar to those obtained for the 1-ml column (Figure 2).

In conclusion, the chromatographic pro- 
A

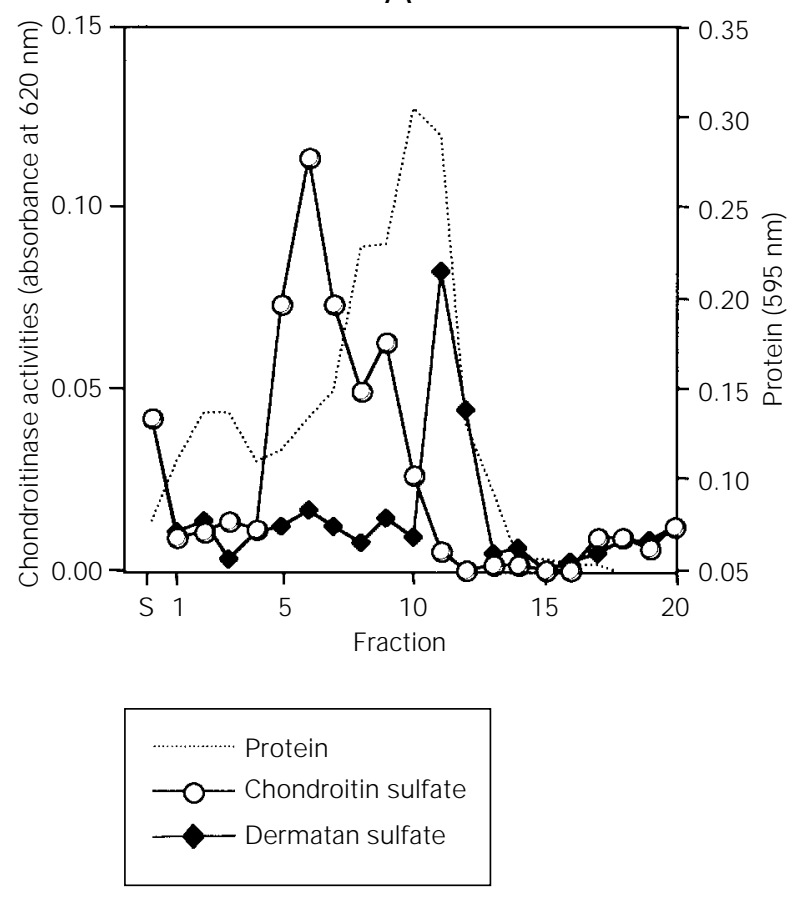

B

Chondroitin sulfate

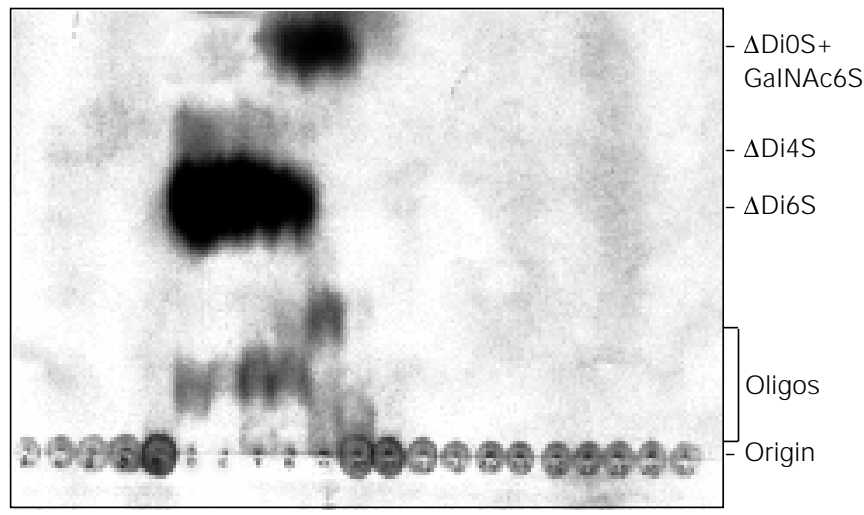

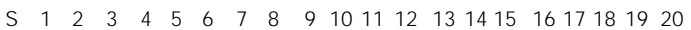

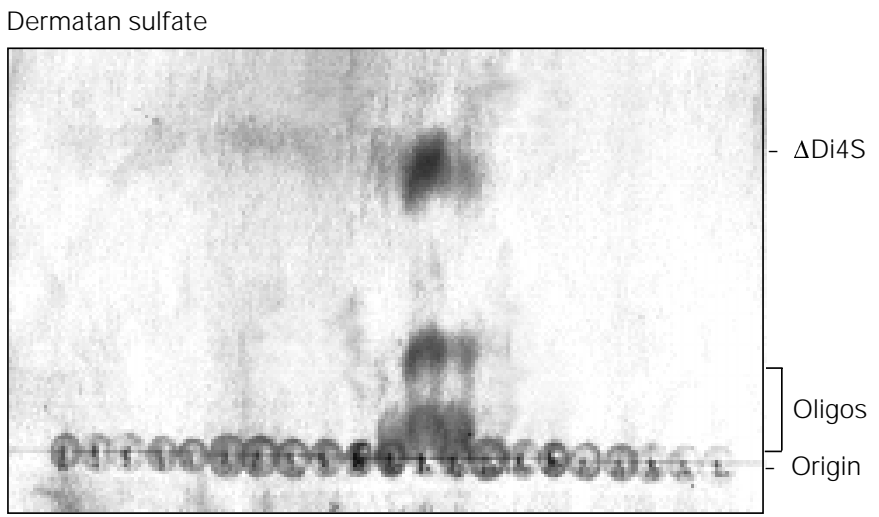

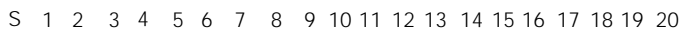

Figure 1 - Fractionation of F. heparinum chondroitinases by high performance (HP) Phenyl-Sepharose chromatography. An aliquot of F. heparinum extract containing $2 \mathrm{mg}$ of protein, $1 \mathrm{M}$ ammonium sulfate and $50 \mathrm{mM}$ Tris-acetate buffer, $\mathrm{pH} 7.5$, was applied to a $0.4 \times 2$-cm column of HP PhenylSepharose previously equilibrated with $1 \mathrm{M}$ ammonium sulfate and $50 \mathrm{mM}$ Tris-acetate buffer, $\mathrm{pH}$ 7.5. The enzymes were eluted in a stepwise fashion with 1-ml solutions containing decreasing concentrations of $\left(\mathrm{NH}_{4}\right)_{2} \mathrm{SO}_{4}$ in the same buffer $(1.00,1.00,0.88,0.75,0.62,0.50,0.38,0.25,0.12 \mathrm{M})$, followed by $10 \mathrm{ml}$ of ammonium sulfate-free buffer, at a flow rate of $0.5 \mathrm{ml} / \mathrm{min}$. One-milliliter fractions were collected and analyzed for protein and chondroitinase activities. Total protein was estimated by the Coomassie blue method (15) and the chondroitinase activities were measured by two methods. A, Dimethylmethylene blue color shift: $10 \mu \mathrm{l}$ of each fraction was incubated with $3 \mu \mathrm{g}$ of chondroitin sulfate or dermatan sulfate in $96-$-well plates. After 4-h incubation at room temperature, $100 \mu \mathrm{l}$ of dimethylmethylene blue reagent (16) was added and the absorbance was measured at 620 $\mathrm{nm}$. B, Paper chromatography: the fractions were dialyzed against $50 \mathrm{mM}$ Tris-acetate buffer, $\mathrm{pH} 7.5$, to remove the ammonium sulfate. Aliquots ( $20 \mu \mathrm{\mu l})$ of each dialyzed fraction were incubated with $50 \mu \mathrm{g}$ of chondroitin sulfate or dermatan sulfate. After overnight incubation at $37^{\circ} \mathrm{C}$ (for chondroitin sulfate) or $20^{\circ} \mathrm{C}$ (for dermatan sulfate), the incubation mixtures were submitted to heat inactivation and paper chromatography as previously described (7). $\Delta$ DiOS: Unsaturated non-sulfated disaccharide; GalNAc6S: N-acetylgalactosamine 6-sulfate; $\Delta$ Di4S: unsaturated 4-sulfated disaccharide; $\Delta$ Di6S: unsaturated 6-sulfated disaccharide; Oligos: oligosaccharides. 


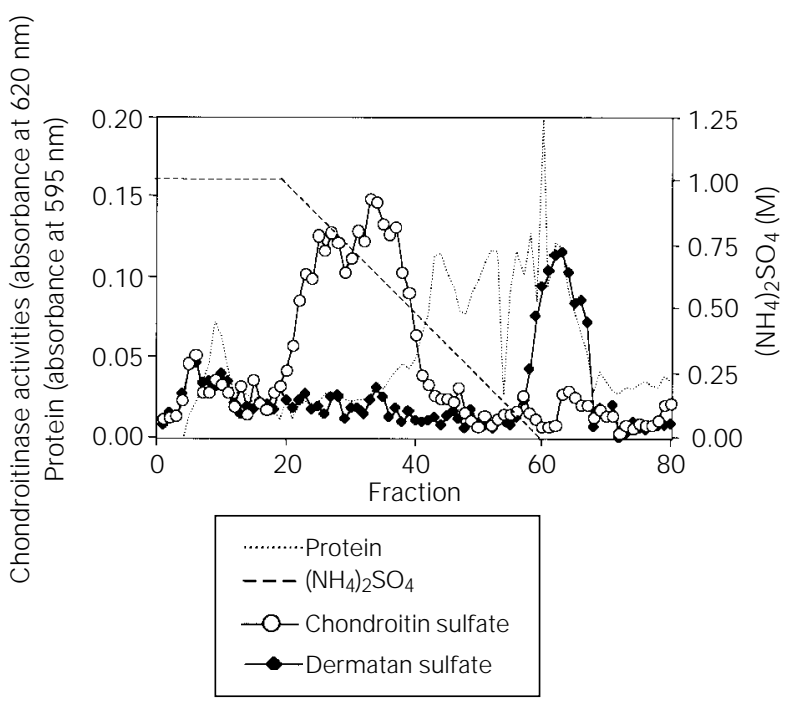

Figure 2 - Large scale preparation of F. heparinum chondroitinases by high performance (HP) Phenyl-Sepharose chromatography. An F. heparinum extract containing $20 \mathrm{mg}$ of protein, $1 \mathrm{M}$ ammonium sulfate and $50 \mathrm{mM}$ Tris-acetate buffer, $\mathrm{pH} 7.5$, was applied to a $1.4 \times 6.5-\mathrm{cm}$ column of HP Phenyl-Sepharose previously equilibrated with $1 \mathrm{M}$ ammonium sulfate and $50 \mathrm{mM}$ Tris-acetate buffer, $\mathrm{pH}$ 7.5. The enzymes were eluted with $1 \mathrm{M}\left(\mathrm{NH}_{4}\right)_{2} \mathrm{SO}_{4}$ in Trisacetate buffer $(40 \mathrm{ml})$, a linear descending gradient of 1 to $0 \mathrm{M}\left(\mathrm{NH}_{4}\right)_{2} \mathrm{SO}_{4}$ in Trisacetate buffer $(80 \mathrm{ml})$ and Tris-acetate buffer $(40 \mathrm{ml})$. Two-milliliter fractions were collected at a flow rate of $1 \mathrm{ml} / \mathrm{min}$. Total protein and chondroitinase activities were estimated as described in Figure 1 (Method 1).

cedure described here based on hydrophobic interaction chromatography on HP PhenylSepharose eluted with decreasing concentrations of ammonium sulfate is suitable for both analytical scale and large scale preparation of Flavobacterium heparinum chondroitinase $\mathrm{AC}$ and chondroitinase $\mathrm{B}$. The chondroitinases were not inhibited by ammonium sulfate and the fractions eluted from the columns could be rapidly assayed by the decrease in the dimethylmethylene blue color shift upon depolymerization of chondroitin sulfate or dermatan sulfate. Prior to the identification of the products by paper chromatography, the ammonium sulfate had to be removed from the enzyme-containing solutions by dialysis.

\section{Reference}

1. Vogel KG (1994). Glycosaminoglycans and proteoglycans. In: Yurchenco PD, Brik DE \& Mechan RP (Editors), Extracellular Matrix Assembly and Structure. Academic Press, Inc., San Diego, CA.

2. Linhardt RJ, Galliher PM \& Cooney CL (1986). Polysaccharide lyases. Applied Biochemistry and Biotechnology, 12: 135176.

3. De Sousa J F, Nader HB \& Dietrich CP (1990). Sequential degradation of chondroitin sulfate in mollusks - desulfation of chondroitin sulfate without prior depolymerization by a novel sulfatase from Anomalocardia brasiliana. J ournal of Biological Chemistry, 265: 20150-20155.

4. Medeiros MGL, Ferreira TMPC, Leite EL, Toma L, Dietrich CP \& Nader HB (1998). New pathway of heparan sulphate degradation. Iduronate sulphatase and $\mathrm{N}$ sulphoglucosamine 6-sulphatase act on the polymer chain prior to depolymerisation by a N-sulpho-glucosaminidase and glycuronidases in the mollusc Tagelus gibbus. Comparative Biochemistry and Physiology. B - Biochemistry and Molecular Biology, 119: 539-547.

5. Yamagata T, Saito $H$, Habuchi $O \&$ Suzuki $S$ (1968). Purification and properties of bacterial chondroitinases and chondrosulfatases. J ournal of Biological Chemistry, 243: 1523-1535.

6. Michelacci YM \& Dietrich CP (1975). A comparative study between a chondroitinase $B$ and a chondroitinase $A C$ from Flavobacterium heparinum. Isolation of a chondroitinase AC-susceptible dodecasaccharide from chondroitin sulphate $B$. Biochemical J ournal, 151: 121-129.

7. Michelacci YM \& Dietrich CP (1976). Chondroitinase $C$ from Flavobacterium heparinum. J ournal of Biological Chemistry, 251: 1154-1158.

8. Michelacci YM , Horton DSPQ \& Población CA (1987). Isolation and characterization of an induced chondroitinase $A B C$ from
Flavobacterium heparinum. Biochimica et Biophysica Acta, 923: 291-301.

9. Michelacci YM \& Dietrich CP (1986). Structure of chondroitin sulphate from whale cartilage: distribution of 6- and 4sulphated oligosaccharides in the polymer chains. International J ournal of Biological Macromolecules, 8: 108-113.

10. Michelacci YM, Mourão PAS, Laredo J \& Dietrich CP (1979). Chondroitin sulfates and proteoglycans from normal and arthrosic human cartilages. Connective Tissue Research, 7: 29-36.

11. Población CA \& Michelacci YM (1986). Structural differences of dermatan sulfates from different origins. Carbohydrate Research, 147: 87-100.

12. Michelacci YM, Laredo J \& Dietrich CP (1981). Proteoglycans and chondroitin sulfates from human multiple chondroma (enchondromatosis). Brazilian J ournal of Medical and Biological Research, 14: 161172. 
13. Gu K, Linhardt RJ, Laliberté M, Gu K \& Zimmermann J (1995). Purification, characterization and specificity of chondroitin lyases and glucuronidase from Flavobacterium heparinum. Biochemical J ournal, 312: 569-577.

14. Ototani N \& Yosizawa Z (1979). Purification of chondroitinase $B$ and chondroiti- nase $C$ using glycosaminoglycan-bound $\mathrm{AH}$-Sepharose 4B. Carbohydrate Research, 70: 295-306.

15. Bradford MM (1976). A rapid and sensitive method for the quantitation of microgram quantities of protein utilizing the principle of protein dye binding. Analytical Biochemistry, 72: 248-254.
16. Farndale RW, Buttle DJ \& Barrett AJ (1986). Improved quantitation and discrimination of sulfated glycosaminoglycans by the use of dimethylmethylene blue. Biochimica et Biophysica Acta, 883: 173-177. 